\title{
The Prohibition of Suicide for Affirmation of Human Beings by Augustine
}

\author{
Makiko Sato \\ Toyama University, Toyama, Japan \\ makiko.sat@gmail.com
}

\section{Summary}

In this paper I examine Augustine's argument about suicide. As is generally known, Augustine argues that suicide is a sin even if it is for saving our honour. This prohibition of suicide is opposite to traditional Roman thought. There was a tradition of people who did not hesitate to die for their faith which was not only in pagan tradition, but also in the Christian church. Through what kind of process of thinking did Augustine adopt the opinion which prohibited suicide? I suggest that Augustine's opinion is not obeying the sixth commandment blindly. It is based on his understanding about human will that he gained through early considerations. I will conclude that Augustine's prohibition of suicide is not necessarily as rigorous as generally supposed. It rather proposes the affirmation of human beings.

\section{Keywords}

suicide - Augustine - Christian martyrdom

\section{1 \\ Augustine's Severe Prohibition of Suicide}

Although the Catholic Church prohibited suicide in the Medieval Ages and had been taking a severe attitude against suicide, there is no direct discussion of suicide in the New Testament. To begin with, Jesus' death can be considered as a certain suicide. The definition of suicide is not surely the same, but when we include a conscious act inducing annihilation to oneself in suicide, Jesus' act in his death on the Cross is considered as a suicide, because he said "what you do, do quickly" to Juda while knowing that he would betray Jesus (Ioh 
27:13). Already in ancient times, for instance Origen said: "Jesus killed himself in a more divine manner." ${ }^{1}$ On the other hand, in the Old Testament, there is a sentence that says "you shall not murder" (Ex 20:13), and sometimes this Mosaic commandment is cited as an authority of the prohibition of suicide in the holy text. However, this is one interpretation. One can interpret also that what Moses prohibits is a killing of others. Moreover, it is possible to interpret that Moses prohibits the killing of all living things, even though there are only a few who believe such an interpretation. Then, where is the basis for the judgement of the prohibition of suicide?

Augustine is the one who interpreted the Moses' sentence as a prohibition of killing oneself. ${ }^{2}$ His prohibition of suicide is known as a very severe and a rigorous one. One of his famous discussions is in the first book of his City of God (De civitate dei). He mentions there for instance about the suicide of Lucretia, who killed herself because she was raped. ${ }^{3}$ Roman people at that time generally had admired her attitude, and even now in modern times, not a few people agree with this Roman admiration. Sometimes such a suicide is looked on as a glorious act for showing one's chastity, or at least as an agreeable act. ${ }^{4}$ Similarly, the case that a commander of an army kills himself before he is captured by the enemy in defeat was admired by Romans. ${ }^{5}$ Augustine, however, judges that the man should not kill himself even to avoiding being captured by the enemy. He prefers Marcus Regulus, who chose to bear capture and harsh torture by the enemy than to kill himself, rather than Macus Cato, who chose to kill himself to avoid being subject to Caesar. ${ }^{6}$ Augustine criticizes Lucretia's and Cato's choices, insisting that Moses' commandment must be understood to mean that you should not kill, neither another nor yourself. 7

1 Origen, Commentary on the Gospel according to John, trans. by R.E. Heine, Washington, D.C., 1993 , p. 190.

2 There is not one word which means 'suicide' at that time. They say just "killing oneself."

3 De civitate dei, 1.19.

4 St. Ambrose (De officiis, 1.18.68) and St. Jerome (Adversus Iovinianum, 1.49) approve that women who were raped commit suicide.

5 Also in Japan's wartime, Japanese people praised soldiers for killing themselves when they were placed under such situation.

6 De civitate dei, 1.24 .

7 De civitate dei, 1.20. Criticizing Lucrecia's act of suicide, Augustine also pleads her chastity. In this discussion, Augustine pays attention to the common point of Lucrecia's and Cato's or Regulus' act, as Malanie Webb points out that "Augustine does not understand rape primarily as a sexual encounter, but as a torture and bereavement". Cf. M. Webb, "On Lucretia who slew herself': Rape and Consolation in Augustine's De civitate dei," Augustinian Studies, 41.1 (2013), pp. $37-58$ (see p. 41$)$. 
The reason for Augustine's interpretation in this discussion is the following. The ninth commandment says: "you should not bear false witness against your neighbour (Ex 20:16)." And in this commandment, no one should think that he is free from blame when he bears false witness against himself, because one who loves his neighbour has received the rule of love based on oneself, since the scripture says: "you should love your neighbour as yourself (Matth 22:39)."8 Augustine connects the Mosaic commandment with the commandment about love in the New Testament. He thinks that the prohibition of homicide is naturally of the neighbour, which comes from neighbourly love, and neighbourly love is based on the love of oneself; therefore this prohibition is also of oneself. This explanation of Augustine's seems to be still open for discussion. The first point is the issue of the validity of the connecting the sentence of the Old Testament with the one of the New Testament. Secondly, both commandments are just commandments. So they are necessarily not persuasive to people who do not have faith in their authority. Therefore, why Augustine expanded this interpretation must be examined.

Georges Minois points out the Platonic influences on Augustine and his strong reaction to Donatist heretics who defend voluntary martyrdom. ${ }^{9} \mathrm{Mi}-$ nois sees agreement with Augustine's thought in the Platonic philosophy that held suicide to be an offence against God's rights. Minois' indication is true. Augustine actually argues that it is not within the charge of murder to kill someone by a command of God. ${ }^{10}$ He attributes the right of claiming a life to God. From this perspective, he regards martyrdom which is not of man's volition, but based on God's will, as free from the charge of suicide. ${ }^{11}$ The argument that one can give validity to suicide depending on the presence of God's will originally comes from the interpretation of Socrates' statement in Phaedo, which says "a man must not kill himself until god sends some necessity upon him."12 It can be said that Augustine's opinion on suicide comes from the agreement of Greek philosophy. Then what consideration led him to this agreement?

8 De civitate dei, 1.20. "Nec ideo tamen si adversus se ipsum quisquam falsum testimonium dixerit, ab hoc crimine se putaverit alienum, quoniam regulam diligendi proximum a semetipso dilector accepit, quando quidem scriptum est: Diliges proximum tuum tamquam te ipsum" (PL, 41).

9 G. Minois, History of Suicide: Voluntary death in Western Culture, trans. by L.G. Cochrane, Baltimore - London, 1995, p.28.

$10 \quad$ De civitate dei, 1.21.

$11 \quad$ De civitate dei, 1.26 .

12 Platon, Phaedon, $62 \mathrm{C}$. 
Before writing the City of God, Augustine expands a discussion on suicide in the third book of On Free Choice of the Will (De libero arbitrio). ${ }^{13}$ After stating that a sin is caused by the sinner's will, Augustine says as follows:

If anyone says 'I prefer not existing to being miserable,' I will reply to him that 'you are not telling the truth. Although you are misery now, you wish to die simply because you wish to exist. Therefore, though you actually do not wish to be miserable, you wish to exist. ${ }^{\prime 14}$

In general, some people justify suicide to escape from unbearable pain or to avoid living in disgrace, as we mentioned earlier about Lucretia and Cato. In such situations, what we prefer is the cancellation of this life. This choice of the cancellation of life is not a choice of "not existing," since to live is to exist. Therefore, it seems that the above statement "I prefer not existing" justly indicates the will of people who want to die. However, Augustine insists that this statement is not true. His explanation is as follows: a person who says "I prefer this one to that one" chooses something; and "not existing" is not anything but "nothing;" therefore, he cannot choose anything if there is nothing to choose. ${ }^{15}$ Augustine points out the irrationality of the statement "I prefer not existing," in that this statement logically means that "I prefer nothing." And according to this logic, it is concluded that one who prefers death prefers to live, because as far as one prefers something, he or she prefers existing. Thus Augustine regards that statement to be false. ${ }^{16}$

It should be noted that Augustine focuses on the multiplicity of a human's will. Also the person who says that he prefers not to exist does not tell a lie

13 De libero arbitrio is supposed to be written in about 395. It is 413 that De civitate dei was begun to write.

14 De libero arbitrio, 3.6.18. "Si enim quis dixerit, Non esse, quam miserum me esse mallem: respondebo, Mentiris. Nam et nunc miser es, nec ob aliud mori non vis, nisi ut sis: ita cum miser nolis esse, esse vis tamen" $(P L, 32)$.

15 De libero arbitrio, 3.6.22.

16 We should take the following point into consideration. Augustine does not regard human death as being nothing. Rather the person who prefers death regards death as being nothing, because he or she thinks that this unbearable life can be cancelled by death. Augustine points out the contradiction in the person who prefers being nothing by death while prefers (being) something. It can be also said that Augustine reveals the arrogance that we judge something as if we know it though we do not know it. (Dr. Jonathan Cahana suggested that I considered this point. I would like to thank him.) 
intentionally, since he does not realize that he wants to exist. A person expects death and sometimes carries out suicide, because he does not notice or esteem the will to exist, while being conscious of the will not to exist. Regarding to such multi-layered will, Augustine argues by using two words: "opinio (opinion, judgement)" and "sensus (sense, feeling)."

An opinion which a person believes or supposes is sometimes true and sometimes false. On the other hand, a sense works on the habit or on the nature. It is easy for us to agree that opinion and sense are different from each other and that 'what we believe we should do' and 'what we delight in doing' are often different. ${ }^{17}$

In this argument, "opinion" is expressed as what we believe (or suppose) we should do, and "sense" is expressed as what we delight in doing. The statement "I prefer not existing" is not a sense but an opinion, because he cannot be delighted when "not existing" is accomplished. On the other hand, when the will to exist is accomplished, one will be delighted, because it prefers a certain being which is free from pain. Therefore, the will for existing is a sense. In the same discussion, Augustine also says that a correct opinion sometimes puts the habit right, and incorrect opinion sometimes misleads the nature. ${ }^{18}$ The relationship of an opinion and a sense is understood that is not a hierarchical but influences each other while searching for the true delight.

Thus it can be seen that Augustine regards suicide as a disagreement of opinion and sense, that is, as a division of will. If we take human's will as far as it is just only a will that we recognize, the pain or the helpless situation seems only what we should avoid. However, as Augustine indicates, if we take the state of human's will including the will which is necessarily not realized, it results that even in despair, there is a will seeking for a delight, because the person prefer existing as far as he or she prefer something. Even a will of suicide is a sign that indicates that we all are to be open to delight. In this discussion, we can see the Augustine's view of human that all human beings have the intention to exist, regardless of the consciousness of themselves. He thinks that human beings have a dimension open to supreme delight that is God within

De libero arbitrio, 3.6.23: "tametsi aliquantum hoc in opinione habeat. Nam opinio aut in errore, aut in veritate ratiocinantis est, vel credentis: sensus autem aut consuetudine, aut natura valet. Posse autem fieri ut aliud sit in opinione, aliud in sensu, vel ex hoc cognoscere facile est, quod plerumque aliud faciendum esse credimus, et aliud facere delectat." De libero arbitrio, 3.6.23: "Solet autem et recta opinio pravam corrigere consuetudinem, et prava opinio rectam depravare naturam: tanta vis est in dominatu et principatu rationis." 
them. However, it seems natural that we humans are influenced by our own will that is conscious than unconscious. Then, in what point does Augustine find a sin of suicide?

3 Thanks for Existence

It never can be that anyone is pleased with not existing. Similarly, there must be never that anyone does not thank the Creator's goodness for his existence. $^{19}$

In this sentence, "Goodness (bonitas)" means kindness and bounty. It means God's kindness of giving existence to every creature. According to the previous discussion that we analyzed above, Augustine's thought here is interpreted as follows. Although we live with pain, if we were not given existence, we could not have will for a better life. And if we do not have will, we are never delighted even if we could receive it. ${ }^{20}$ As a result, it can be said that the giving of existence by the Creator makes it possible for us to live with delight and to gain happiness. So we should thank that we are now given existence. Augustine's thought surely reflects Platonic ontology that every existence participates of the supreme existence. And also it reflects the creationism based on the Bible. What is to be noted is that Augustine relates the concept of delight and thanks to ontology and creation. He accepted them and understood that it is for making us to live in happiness that the supreme existence gives existence to all beings and that the Creator creates them. He thinks that a will for living with delight is not but a desire for supreme existence. Therefore, to love the fact that we are living now is only way to live with delight.

Augustine never prohibits suicide definitely in that discussion in the Free Choice of the Will. He only encourages people to be grateful that we are living now. It is supposed that the same understanding is the basis of the discussion in City of God. If suicide is caused by the division of the will, the sin of suicide is seen in the will which does not intend to exist, because it prevents the man

19 De libero arbitrio, 3.6.23: "Quapropter, sicut nullo pacto fieri potest ut non esse aliquem libeat; ita nullo pacto fieri oportet ut ex eo quod est quisque, bonitati Creatoris ingratus sit."

20 Augustine thinks that will (love) is inevitably needed for happiness. Cf. De moribus ecclesiae Catholicae et de moribus manichaeorum, 1.3.4 "Beatus autem, quantum existimo, neque ille dici potest, qui non habet quod amat, qualecumque sit, neque qui habet quod amat, si noxium sit, neque qui non amat quod habet, etiamsi optimum sit" $(P L, 32)$. 
from reaching supreme happiness. And the supreme happiness is God that is the supreme existence. Therefore, in other words, as far as the will does not separate from God, it cannot be a sin. And as we see above, the will to exist is in a depth dimension inside of human beings. That means that other people cannot judge ultimately whether the person's will separates from God or not, because no one cannot see inside others. God is the being that gives existence and takes it away. When God's will is to take the existence away, a murder depends on God's will. ${ }^{21}$ Therefore, a suicide which depends on God's will can be seen to be free from a sin. In fact, in the discussion in City of God, Augustine insists that martyrdom according to God's command is not a sin.

Someone who is told that he should not kill himself can do kill himself if the command is given by the one whose command should not be ignored. Just he should know whether the divine command is never precarious by uncertain thing. We meet other's consciousness through the ear and we do not obtain the hidden things from us. ${ }^{22}$

Georges Minois regards the examples of martyrs as exceptions in Augustine's scheme about suicide, ${ }^{23}$ but the above argument leads us to presume that $\mathrm{Au}$ gustine derives his opinion about martyrdom from the same ontology as that from which he derives his opinion that anyone should not commit suicide. The statement about the difficulty of knowing other's mind indicates that this argument in City of God is based on the understanding about multi-layered will. If we do not know other's mind, we do not have a right to judge others. Augustine's prohibition of suicide does not aim to judge and blame someone's act. He leads people's intention to God and promotes thanks for living. Whether a suicide is a sin depends on whether the person loves God.

21 While explaining the difference between martyrdom and suicide in Augustine's discussion, Kaufman points out the ambiguity of these terms. "Martyrs are not suicides because they do not seek death but rather accept it when given. Augustine is aware that this is a difficult line to draw." Cf. P.I. Kaufman "Augustine's dystopia," in: Augustine’s City of God: A Critical Guide, ed. by J. Wetzel, Cambridge, 2012, p. 51.

22 De civitate dei, 1.26 "Qui ergo audit non licere se occidere, faciat, si iussit cuius non licet iussa contemnere; tantummodo videat utrum divina iussio nullo nutet incerto. Nos per aurem conscientiam convenimus, occultorum nobis iudicium non usurpamus."

23 G. Minois, History of Suicide: Voluntary Death in Western Culture, p. 29, n. 10. 


\section{Conclusion}

Augustine's discussion of suicide is based on the agreement with the platonic ontology which leads him to pay attention to the unconscious but fundamental of man's will to exist. According to this understanding of will, Augustine thinks that every being is a gift from the supreme existence and that the will to exist is the only way for us human beings to the true happiness. What should be noted is that, prohibiting suicide, Augustine points out that we cannot see the other's mind. He promotes people to turn down their arrogance which esteems only conscious will. It should be reminded that Augustine recognizes his weakness which cannot be free from a sin without God's aid, by examining his own conscious and unconscious will in the book 10 of Confessions. ${ }^{24}$ Understanding the human's will which includes unconscious will, a man accepts humility when he is conscious of own weakness. When people affirm suicide, they consider a certain existence as worthless for being. In other words, they have conditional love for life. In having unconditional love for every being, Augustine finds the accordance with God, since to have such a love is to be similar to God who has unconditional love.

24 Confessions, 10.30.41-41.66. 